\title{
Decomposing the Dividend ${ }^{1}$
}

\begin{tabular}{|c|c|}
\hline E. Grifell-Tatjé & C. A. Knox Lovell \\
\hline Departament d'Economia de l'Empressa & Department of Economics \\
\hline Universitat Autònoma de Barcelona & University of Georgia \\
\hline 08193 Bellaterra (Barcelona), Spain & Athens, GA 30602, USA \\
\hline
\end{tabular}

This is a postprint version of the article that was published in Grifell-Tatjé, E. and C.A. Knox Lovell (2004), "Decomposing the Dividend," Journal of Comparative Economics vol. 32, issue 3, pages 500 - 518.

DOI: $10.1016 /$ j.jce.2004.05.002

Corresponding author: C. A. Knox Lovell, Department of Economics, University of Georgia, Athens, GA 30602, USA, knox@terry.uga.edu 
Grifell-Tatjé, E. and C.A. Knox Lovell (2004), "Decomposing the Dividend," Journal of Comparative Economics vol. 32, issue 3, pages 500 - 518.

DOI: $\underline{10.1016 / \mathrm{j} . j \mathrm{jce} .2004 .05 .002}$

\begin{abstract}
Most theoretical and empirical research on cooperatives focuses on the comparative statics behavior of optimizing cooperatives. We focus on the magnitude and sources of variation in the dividend that cooperatives are presumed to maximize. Variation in the dividend leads to an inefficient allocation of labor among cooperatives. For a panel of 59 Spanish cooperative financial institutions, from 1994 to 2001, we decompose dividend variation into mutually exclusive and exhaustive sources. We also compare the performance of all other cooperative financial institutions to that of Caja Laboral Popular, which provides financial services to the Mondragón group of cooperatives.
\end{abstract}

Journal of Economic Literature classification numbers: J54, D24, G21 
Grifell-Tatjé, E. and C.A. Knox Lovell (2004), "Decomposing the Dividend," Journal of Comparative Economics vol. 32, issue 3, pages 500 - 518.

DOI: $10.1016 /$ j.jce.2004.05.002

\section{Introduction}

Dividend-seeking cooperatives experience variation in their achieved dividend similar to the variation in profit found among profit-seeking capitalist firms. In testing various hypotheses about the comparative static behavior of cooperatives and contrasting their behavior to that of profit-seeking capitalist twins, empirical research has overlooked this variation in the dividend. The possibility of perverse behavior was introduced by Ward (1958) and Domar (1966) and has been analyzed by many subsequent writers, e.g., Neary (1988) and Kahana (1989). Pencavel (2001) surveys the related comparison literature.

In this study, we develop an analytical framework within which we examine the dividend performance of a panel of 59 Spanish cooperative financial institutions (CFIs) from 1994 to 2001. We are not concerned with possible perversities in the behavior of optimizing cooperatives or in comparing their behavior to that of their twin savings and commercial banks. ${ }^{2}$

We quantify the extent of variation in the dividend among these institutions and identify its sources. Throughout the eight-year period, the coefficient of variation of the dividend averages 0.33 with a maximum value more than twice the mean and a minimum value less than half the mean. This substantial variation has not decreased over time.

Variation in dividends leads to an inefficient allocation of labor among cooperatives. As Bonin et al. (1993) note, dividend-seeking cooperatives adjust employment to the point where the value of labor's marginal product 
Grifell-Tatjé, E. and C.A. Knox Lovell (2004), "Decomposing the Dividend," Journal of Comparative Economics vol. 32, issue 3, pages 500 - 518.

DOI: $10.1016 /$ j.jce.2004.05.002

equals the endogenously determined dividend rather than to an exogenously determined wage rate as in a capitalist economy. Hence, variation in the dividend implies variation in the value of labor's marginal product, which signals an inefficient allocation of labor among cooperatives.

In a capitalist economy, the discipline of competition, in conjunction with the free mobility of resources to foster entry and exit, should decrease profit variation over time. However, dividend variation may persist in a cooperative economy in the absence of a complete market in transferable employment rights (Ireland and Law, 1981). Bradley and Gelb (1982) suggest that dividends vary because of entry screening procedures and exit costs, both of which constrain labor from moving to high-dividend cooperatives. The trade association of Spanish CFls, Unión Nacional de Cooperativas de Crédito (UNACC), specifies general guidelines within which individual CFIs are free to set constraints on labor mobility. The guidelines consist of a nominal entry fee, no exit restrictions after a minimum tenure of five years, and permission for individual CFls to impose more stringent restrictions. Although these guidelines do constrain labor mobility, they are much less restrictive than those imposed by the Mondragón Corporación Cooperativa. ${ }^{3}$

Even within a homogenous sector such as financial institutions, in which human capital is transferable, cultural barriers and individual preferences constrain severely labor mobility among regionally dispersed CFIs. ${ }^{4}$ As a result, the market in transferable employment rights is incomplete, so that dividend variation with its resulting inefficient labor allocation are 
Grifell-Tatjé, E. and C.A. Knox Lovell (2004), "Decomposing the Dividend," Journal of Comparative Economics vol. 32, issue 3, pages 500 - 518.

DOI: $10.1016 /$ j.jce.2004.05.002

sustainable over time. Since dividend variation is large and sustained among Spanish CFIs, we investigate its sources.

In Section 2, we provide background information on the institutional environment within which Spanish CFIs operate. In Section 3, we develop an analytical framework to provide an informative decomposition of the variation in dividends. This decomposition requires information on unobserved input-output combinations; in Section 4, we explain how the unobserved input- output combinations can be computed from observed data. In Section 5, we describe our sample of Spanish CFls and provide a complete decomposition of the variation in dividends, both over time and across cooperatives. Section 6 reports a pair of cross-sectional benchmarking exercises, in which the performance of all other CFIs is compared to that of Caja Laboral Popular (CLP), which provides financial services to the Mondragón cooperative group. Section 7 concludes with a summary of our findings and discusses their implications for the misallocation of labor in this sector.

\section{Background Information}

The first CFI in Spain, Papeleros de Buñol, was founded in Valencia in 1858, although CFls did not flourish until the turn of the twentieth century, with the appearance of Cajas Rurales (CR). CRs were associated with the Catholic Church, and provided financial services to agricultural cooperatives and individual farmers. Prior to the Spanish Civil War, more than 1,000 CRs 
Grifell-Tatjé, E. and C.A. Knox Lovell (2004), "Decomposing the Dividend," Journal of Comparative Economics vol. 32, issue 3, pages 500 - 518.

DOI: $10.1016 /$ j.jce.2004.05.002

operated, although this number has fluctuated around a declining trend as some cooperatives have transformed into savings banks and others have disappeared. Beginning in 1959 and continuing through 1983, another type of CFI, namely Cajas Populares y Profesionales (CPP), was established to provide financial services to industrial cooperatives, e.g., the Mondragón group, and to professional cooperatives, e.g., architects, attorneys and engineers. In 2001, the population of CFls consisted of 81 CRs and seven CPPs. Through their trade association, UNACC, all CFIs belong to the International Cooperative Alliance. As a group, CFIs hold $4 \%$ of total assets in the Spanish banking system, of which savings banks have $40 \%$ and commercial banks $56 \%$.

According to the decree Real Decreto 2860/1978, the Spanish Central Bank regulates CFIs, in the same manner as it regulates commercial and savings banks. In addition, CFIs are governed by legislation pertaining specifically to cooperative organizations. A sequence of decrees, going back at least to the Ley de Cooperativas of 1942, imposes limits on CFI membership. Enacted during the Franco regime, this law also imposed restrictions on democratic organization of CFls, and constrained the growth of CPPs. The document Ley 13/1989 defines the objective of CFIs to be the provision of financial services to their members and to other people, firms or institutions. The original requirement that $\mathrm{CR}$ members be agricultural cooperatives and their members and CPP members be industrial or professional cooperatives and their members has been relaxed. In addition, 
Grifell-Tatjé, E. and C.A. Knox Lovell (2004), "Decomposing the Dividend," Journal of Comparative Economics vol. 32, issue 3, pages 500 - 518.

DOI: $10.1016 /$ j.jce.2004.05.002

membership in both types of CFI is not restricted to their target clientele and may include related cooperatives, individuals and other institutions. However, Ley $13 / 1989$ limits to $50 \%$ the share of financial transactions that can be conducted with other people, firms or institutions and requires individual members to live in the zone of influence of the CFI. The only additional restriction on membership is the requirement that a member deposit and retain at least 60 euros in a capital account and be approved by the Asamblea General of the CFI. No penalty is imposed for departing after a five-year membership.

This legal structure imposes modest restrictions on membership and hence on labor mobility. However, individual CFIs may impose higher entry fees and additional restrictions. Given the modest restrictions, CFI membership typically consists of thousands of individuals and from a few to a few hundred related cooperatives and other institutions. However, CFIs typically have a labor force that is only a small fraction of the number of individual members. Employees are members, but not conversely, with two exceptions. CLP and Caixa Popular (CP), a similar CPP established in 1978 to serve the industrial cooperatives in the Valencia area, have approximately the same number of employees as individual members. In these two CFIs, individual members must be employees. Employee wage rates are determined by triennial negotiations, called the Convenio Colectivo, between UNACC and the trade union. Negotiated minimum wages vary by job classification but, within each classification, they are uniform across CFIs. 
Grifell-Tatjé, E. and C.A. Knox Lovell (2004), "Decomposing the Dividend," Journal of Comparative Economics vol. 32, issue 3, pages 500 - 518.

DOI: $10.1016 /$ j.jce.2004.05.002

Thus, any observed wage variation reflects some combination of skill variation, variation in the mix of full-time and part-time employment, and payment of above-minimum wages.

Profit is the difference between revenue and expense, which includes the remuneration of employees. Initially, profit is allocated to the payment of income tax and to the payment of interest on member capital accounts. Members receive the precio legal del dinero, currently $4.25 \%$, plus a maximum of $6 \%$ on their capital accounts, giving them an incentive to deposit more than the minimum requirement. Remaining profit, called available surplus, is allocated to a mandatory contribution to the reserve fund, at least $20 \%$, a mandatory contribution to the education and promotion fund, at least $10 \%$, and discretionary cooperative rebates, which the Asamblea General is free to allocate as a voluntary contribution to the reserve fund, as an additional contribution to members' capital accounts, or to other uses.

The Asamblea General is at the heart of the CFI governance structure; delegates are elected to the Asamblea General in local, typically branch office, meetings. Each delegate has one vote unless the CFI statute specifies voting in proportion to a delegate's capital contribution. The Asamblea General sets the interest rate on member capital accounts and establishes rules governing the allocation of the available surplus. It also elects the Consejo Rector, which is the governing council of the CFI. Among other duties, this body appoints the CEO and the executive board of the CFI. The Consejo Rector usually has from five to 15 members, at least one of which 
Grifell-Tatjé, E. and C.A. Knox Lovell (2004), "Decomposing the Dividend," Journal of Comparative Economics vol. 32, issue 3, pages 500 - 518.

DOI: $10.1016 /$ j.jce.2004.05.002

must be an employee representative. Thus, employee involvement in the Asamblea General influences the distribution of benefits between employees and non-employee members and, through the Consejo Rector, the business strategies that determine these benefits.

In practice, CFls vary in determining interest payments on member capital accounts and distributing the available surplus. In 2001, mandatory contributions to the reserve fund ranged from the statutory minimum up to $90 \%$ and mandatory contributions to the education and promotion fund ranged from the statutory minimum up to $40 \%$. Consequently the discretionary residual allocated by the Asamblea General ranged from zero up to $70 \%$. This variation could depend on varying degrees of employee participation in CFI decision-making. Since we have no direct evidence on employee participation, we cannot test hypotheses concerning the effect of participation on performance as Estrin et al. (1987) do for other cooperatives. Nonetheless, we have compelling evidence to support the hypothesis that CFI governance serves in the general interest of its employees, rather than its members. ${ }^{5}$

First, employee benefits exceed considerably the negotiated minimum wages, and non-employee members do not receive these benefits. ${ }^{6}$ Second, the interest rate paid on member capital accounts averages $4.8 \%$, which is close to the statutory minimum, and reflects a tendency to retain after-tax profit within the CFI. Third, excluding CLP and CP, CFIs allocate $75 \%$ of the available surplus to the reserve fund, which exceeds considerably the 
Grifell-Tatjé, E. and C.A. Knox Lovell (2004), "Decomposing the Dividend," Journal of Comparative Economics vol. 32, issue 3, pages 500 - 518.

DOI: $10.1016 /$ j.jce.2004.05.002

mandatory minimum of $20 \%$. These funds are retained within the CFI rather than distributed to members. Fourth, CFIs allocate $15 \%$ of the available surplus to the education and promotion fund, which is close to the mandatory minimum but also part of the generous employee benefits. Fifth, most of the available surplus disbursed at the Asamblea General takes the form of voluntary payments to the reserve fund, which reinforces the tendency to retain funds within the $\mathrm{CFI}$ rather than to distribute them to members. ${ }^{7}$

This distributional evidence is relevant to the question of whether CFIs are labor-managed firms or member-managed firms. In a pure labor-managed firm of the Ward - Domar type, members and employees coincide, so that the issue does not arise. In the subsequent literature, decision-making power rests with members, who may hire employees. Hence, optimizing behavior may lead to shrinking membership and expanding hired employment so that the firm degenerates to its capitalist twin (Ben - Ner, 1984, Miyazaki, 1984). In contrast, Spanish CFIs allow employees to exert disproportionate control in at least the distributional aspects of managerial decision-making. In addition, the member/employee ratio increases in CFls, because employee selfinterest requires a sufficient number of members to provide the deposits to fund profitable loans. This incentive is reinforced by Ley 13/1989, which limits to $50 \%$ the share of financial transactions conducted with other people, firms or institutions. Without much access to external financing, CFIs expand the number of members. At the same time, employment growth is constrained because much of the available surplus is returned, directly or indirectly, to 
Grifell-Tatjé, E. and C.A. Knox Lovell (2004), "Decomposing the Dividend," Journal of Comparative Economics vol. 32, issue 3, pages 500 - 518.

DOI: $10.1016 /$ j.jce.2004.05.002

employees. Thus, we characterize CFIs as labor-managed firms that require members to provide financing to support growth opportunities.

\section{The Analytical Framework}

Following the tradition initiated by Ward and Domar, we assume that cooperatives seek to maximize the dividend, or value added per employee. The dividend, denoted $\mathrm{D}$, is defined as:

$$
D \equiv\left(\pi+w_{L} L\right) / L=\left(p Y-w^{\top} X\right) / L=p(Y / L)-w^{\top}(X / L)
$$

where $\pi$ represents the available surplus after taxes and interest payments on member accounts, $w_{L}$ represents the wage and $L$ represents the labor input. Value added, denoted by $p Y-w^{\top} X$, is equal to revenue $p Y$, where $p$ and $Y$ are scalar output price and quantity, minus non-labor expense $\mathbf{w}^{\top} \mathrm{X}$, where $\mathrm{w}$ and $X$ are price and quantity vectors of other inputs and $T$ is the transpose operator. Thus, employee income consists of a wage, $\mathrm{w}_{\mathrm{L}}$, and the available surplus per employee, $\pi / \mathrm{L}$. Although restrictions are imposed on the distribution of the available surplus, most of it is retained within the cooperative; very little is distributed to non-member employees.

From the first equality in equation (1), the variation in the dividend can be attributed to variations in quantities, i.e., $Y, X$ and $L$, and to variations in prices, i.e., $p$ and $w$. The second equality indicates that dividend variation also 
Grifell-Tatjé, E. and C.A. Knox Lovell (2004), "Decomposing the Dividend," Journal of Comparative Economics vol. 32, issue 3, pages 500 - 518.

DOI: $\underline{10.1016 / \mathrm{j} . j \mathrm{jce} .2004 .05 .002}$

depends on variation in the value of labor productivity, i.e., $p(Y / L)$, and to variation in the cost of other inputs per worker, i.e., $w^{\top}(X / L)$, which we refer to as the cost of input deepening. Furthermore, dividend variation may be influenced by differences in technology, by differences in the cost efficiency with which other inputs are allocated, and by an activity effect that reflects the ability to convert input deepening into increased labor productivity. Figure 1 illustrates these decompositions of the variation in the dividend.

\section{Insert Figure 1 about here}

We develop an intertemporal decomposition from period t to period $t+1$, although the same approach could also be used to generate a multilateral decomposition. Denoting output per worker, i.e., $\mathrm{Y} / \mathrm{L}$, as $\mathrm{y}$ and the normalized input vector, i.e., $\mathrm{X} / \mathrm{L}$, as $\mathrm{x}$, in equation (1) we have:

$$
D^{t+1}-D^{t}=\left[\left(p^{t+1}-p^{t}\right) y^{t+1}-\left(w^{t+1}-w^{t}\right)^{T} x^{t+1}\right]+\left[\left(y^{t+1}-y^{t}\right) p^{t}-\left(x^{t+1}-x^{t}\right)^{T} w^{t}\right],(2)
$$

and

$$
D^{t+1}-D^{t}=\left[\left(p^{t+1}-p^{t}\right) y^{t}-\left(w^{t+1}-w^{t}\right)^{T} x^{t}\right]+\left[\left(y^{t+1}-y^{t}\right) p^{t+1}-\left(x^{t+1}-x^{t}\right)^{T} w^{t+1}\right] \cdot(3)
$$


Grifell-Tatjé, E. and C.A. Knox Lovell (2004), "Decomposing the Dividend," Journal of Comparative Economics vol. 32, issue 3, pages 500 - 518.

DOI: $\underline{10.1016 / \mathrm{j} . j \mathrm{jce} .2004 .05 .002}$

Equation (2) combines Paasche-type price changes using comparison period quantity weights with Laspeyres-type quantity changes using base period price weights; equation (3) does the opposite.

Since both Paasche and Laspeyres indexes suffer from well-known shortcomings, we combine equations (2) and (3) to obtain:

$$
\begin{aligned}
D^{t+1}-D^{t} & =\left\{\left[1 / 2\left(y^{t+1}+y^{t}\right)\right]\left(p^{t+1}-p^{t}\right)-\left[1 / 2\left(x^{t+1}+x^{t}\right)\right]^{\top}\left(w^{t+1}-w^{t}\right)\right\} \\
& +\left\{\left[1 / 2\left(p^{t+1}+p^{t}\right)\right]\left(y^{t+1}-y^{t}\right)-\left[1 / 2\left(w^{t+1}+w^{t}\right)\right]^{\top}\left(x^{t+1}-x^{t}\right)\right\} .
\end{aligned}
$$

Equation (4) uses arithmetic mean quantities to weight price changes and arithmetic mean prices to weight quantity changes. The four components of (4) are price and quantity indicators of the type proposed by Bennet (1920); they are difference form analogs of ratio form Fisher price and quantity indexes. Whereas Fisher indexes are geometric means of Paasche and Laspeyres indexes, Bennet indicators are arithmetic means of Paasche and Laspeyres indicators. Bennet price and quantity indicators satisfy several desirable axioms analogous to those satisfied by Fisher price and quantity indexes. $^{9}$

The first term on the right side of (4) is the price effect, denoted $\Delta \mathrm{P}$ in Figure 1. This term measures the contribution of price changes, holding quantities fixed at their arithmetic mean values, to changes in the dividend. The price effect is the difference between an output price effect and an input 
Grifell-Tatjé, E. and C.A. Knox Lovell (2004), "Decomposing the Dividend," Journal of Comparative Economics vol. 32, issue 3, pages 500 - 518.

DOI: $10.1016 /$ j.jce.2004.05.002

price effect. An increase in the output price increases the dividend, while increases in other input prices reduce the dividend. The second term is the quantity effect, denoted $\Delta \mathrm{Q}$ in Figure 1 ; it measures the contribution of quantity changes, holding prices fixed at their arithmetic mean values, to changes in the dividend. The quantity effect is the difference between a labor productivity effect, denoted $\Delta(\mathrm{Y} / \mathrm{L})$ in Figure 1, and an input deepening effect, denoted $\Delta(\mathrm{X} / \mathrm{L})$ in Figure 1. Input deepening decreases the dividend because other inputs are costly, but it enhances labor productivity, which increases the dividend. ${ }^{10}$ The quantity effect can be decomposed further as the following proposition demonstrates. $^{11}$

Proposition: The quantity effect decomposes as follows:

$$
\begin{aligned}
& \left\{\left[1 / 2\left(p^{t+1}+p^{t}\right)\right]\left(y^{t+1}-y^{t}\right)-\left[1 / 2\left(w^{t+1}+w^{t}\right)\right]^{T}\left(x^{t+1}-x^{t}\right)\right\} \\
& =-\left[1 / 2\left(w^{t+1}+w^{t}\right)\right]^{\top}\left[\left(x^{t+1}-x_{C E}^{t+1}\right)-\left(x^{t}-x_{C E}^{t}\right)\right] \quad \text { cost efficiency effect } \\
& +\left[1 / 2\left(p^{t+1}+p^{t}\right)\right]\left(y^{A t}-y^{t}\right) \quad \text { technology effect } \\
& +\left\{\left[1 / 2\left(p^{t+1}+p^{t}\right)\right]\left(y^{t+1}-y^{A t}\right)-\left[1 / 2\left(w^{t+1}+w^{t}\right)\right]^{\top}\left(x_{C E}{ }^{t+1}-x_{C E}\right)\right\} \text { activity effect }
\end{aligned}
$$

This proposition is illustrated in Figure 2. The production sets in periods $t$ and $t+1$ are labeled $T^{t}$ and $T^{t+1}$. Production in period $t$ uses $x^{t}$ to 
Grifell-Tatjé, E. and C.A. Knox Lovell (2004), "Decomposing the Dividend," Journal of Comparative Economics vol. 32, issue 3, pages 500 - 518.

DOI: $\underline{10.1016 / \mathrm{j} . j \mathrm{jce} .2004 .05 .002}$

produce $\mathrm{y}^{\mathrm{t}}$, which is interior to $\mathrm{T}^{\mathrm{t}}$. Production in period $\mathrm{t}+1$ uses $\mathrm{x}^{\mathrm{t}+1}$ to produce $y^{t+1}$, which is interior to $T^{t+1}$. The quantity effect is indicated by the arrow connecting $\left(\mathrm{x}^{\mathrm{t}}, \mathrm{y}^{\mathrm{t}}\right)$ with $\left(\mathrm{x}^{\mathrm{t}+1}, \mathrm{y}^{\mathrm{t}+1}\right)$, which can be decomposed as follows. The first component is a cost efficiency effect, which is indicated by the horizontal arrows connecting observed $\left(\mathrm{x}^{\mathrm{t}}, \mathrm{y}^{\dagger}\right)$ with cost-efficient $\left(\mathrm{XCE}^{\mathrm{t}}, \mathrm{y}^{\dagger}\right)$ and observed $\left(\mathrm{x}^{\mathrm{t}+1}, \mathrm{y}^{\mathrm{t}+1}\right)$ with cost-efficient $\left(\mathrm{x}_{C E}^{\mathrm{t}+1}, \mathrm{y}^{\mathrm{t}+1}\right)$. This component contributes to or detracts from the dividend change as other inputs are allocated in a more or less cost-efficient manner in period $t+1$ than they were in period $t$, with the change being evaluated at arithmetic mean input prices.

\section{Insert Figure 2 about here}

The second component is a technology effect, which is indicated by the vertical arrow connecting cost-efficient $\left(\mathrm{XCE}_{\mathrm{CE}}^{\mathrm{t}}, \mathrm{y}^{t}\right)$ on the boundary of $\mathrm{T}^{\mathrm{t}}$ with cost-efficient $\left(\mathrm{X}_{C E}{ }^{\mathrm{t}}, \mathrm{y}^{\mathrm{At}}\right)$ on the boundary of $\mathrm{T}^{\mathrm{t}+1}$. Output per worker of $\mathrm{y}^{\mathrm{At}}$ is feasible with cost-efficient $X_{C E}{ }^{t}$ and new technology $T^{t+1}$. This component contributes to or detracts from the dividend change as the value of output per worker is enhanced or reduced by the new technology, with the change being evaluated at arithmetic mean output prices. The final component is an activity 
Grifell-Tatjé, E. and C.A. Knox Lovell (2004), "Decomposing the Dividend," Journal of Comparative Economics vol. 32, issue 3, pages 500 - 518.

DOI: $10.1016 /$ j.jce.2004.05.002

effect, which is indicated by the arrow connecting cost-efficient $\left(X_{C E}{ }^{t}, y^{A t}\right)$ with cost-efficient $\left(\mathrm{XCE}^{\mathrm{t}+1}, \mathrm{y}^{\mathrm{t}+1}\right)$. Since both points are on the boundary of $\mathrm{T}^{\mathrm{t}+1}$, the activity effect contributes to or detracts from the dividend change as the change in the value of output per worker exceeds or falls short of the change in the cost of other inputs per worker, with the changes being evaluated at arithmetic mean output and input prices. Thus, the activity effect is a quantity effect that is net of changes in technology and changes in cost efficiency and is expressed in value terms. ${ }^{12}$

To summarize, dividend variation is attributable partly to variation in the prices cooperatives receive for their products and variation in the prices they pay for their non-labor inputs. In addition, dividend variation is attributable to variation in quantities, which consists of the variation in the value of output per worker less the variation in the cost of other inputs used per worker. The proposition demonstrates that variation in quantities can be partitioned into three components, namely variation in cost efficiency, variation in technology, and an activity effect. We quantify these three sources of dividend variation.

\section{The Decomposition}

The decomposition into price and quantity effects and the decomposition of the quantity effect into labor productivity and input deepening effects can be achieved by straightforward computations based on 
Grifell-Tatjé, E. and C.A. Knox Lovell (2004), "Decomposing the Dividend," Journal of Comparative Economics vol. 32, issue 3, pages 500 - 518.

DOI: $10.1016 /$ j.jce.2004.05.002

observed data. However, the decomposition of the quantity effect into the three effects identified in the proposition involves computations based on three pieces of unobserved data, namely, the cost-efficient normalized input vectors denoted $\mathrm{X}_{\mathrm{CE}}{ }^{\mathrm{t}}$ and $\mathrm{X}_{\mathrm{CE}}{ }^{\mathrm{t}+1}$, and the normalized output using the new technology, denoted $y^{A t}$. Since $x_{C E}{ }^{t}$ and $x_{C E}{ }^{t+1}$ are cost-efficient normalized input vectors located on the boundaries of $\mathrm{T}^{\mathrm{t}}$ and $\mathrm{T}^{\mathrm{t}+1}$ respectively and since $\mathrm{y}^{\mathrm{At}}$ is a maximum normalized output located on the boundary of $\mathrm{T}^{\mathrm{t}+1}$, frontier techniques are appropriate. We use an extension of Data Envelopment Analysis (DEA), which is a linear programming technique introduced by Charnes et al. (1978) to evaluate producer performance. ${ }^{13}$ The technique constructs best practice frontiers, which provide empirical approximations to the boundaries of $\mathrm{T}^{\mathrm{t}}$ and $\mathrm{T}^{\mathrm{t}+1}$, and measures the performance of each producer relative to the best practice observed in the sample.

To identify $\mathrm{XCE}^{\mathrm{t}}$ and $\mathrm{X}_{\mathrm{CE}}{ }^{\mathrm{t}+1}$ we construct production frontiers for years $\mathrm{t}$ and $t+1$ and we compare these production frontiers to identify $y^{A t}$. In conventional DEA, a best practice frontier for year $t$ is constructed from data on all producers in year t. Consequently, best practices in previous years are not used in year t. Our extension allows the best practice in year $t$ to be constructed from data on all producers in all years prior to and including year t. Hence, best practices in previous years are remembered and remain available for adoption in the current year. ${ }^{14}$ 
Grifell-Tatjé, E. and C.A. Knox Lovell (2004), "Decomposing the Dividend," Journal of Comparative Economics vol. 32, issue 3, pages 500 - 518.

DOI: $\underline{10.1016 / \mathrm{j} . j \mathrm{jce} .2004 .05 .002}$

We define the feasible set of production activities in year $t$ as:

$$
\mathrm{T}^{\mathrm{t}}=\left\{(\mathrm{y}, \mathrm{x}): \mathrm{y} \leqq \sum_{i} \lambda_{\mathrm{i}} \mathrm{y}_{\mathrm{i}}^{\mathrm{s}}, \mathrm{x} \geqq \sum_{\mathrm{i}} \lambda_{\mathrm{i}} \mathrm{x}_{\mathrm{i}}^{\mathrm{s}}, \lambda_{\mathrm{i}} \geqq 0, \sum_{\mathrm{i}} \lambda_{\mathrm{i}}=1, \mathrm{~s}=1, \ldots, \mathrm{t}\right\}
$$

Hence, $(y, x)$ is bounded above by a piecewise linear envelope characterizing the best practice observed in all years from year 1 through year $t$ inclusive. In year $t$, output per worker y cannot exceed a convex combination of output per worker of all cooperatives in all years prior to and including year $t$, denoted by $\sum_{i} \lambda_{i} y_{i}{ }^{s}$. Similarly, in year $t$ the normalized input vector $x$ cannot be smaller than a convex combination of normalized input vectors of all cooperatives in all years prior to and including year t, denoted by $\sum_{i} \lambda_{i} x_{i}^{s}$. Thus, the vector $\lambda$ has dimension $I_{1}$ in year $1, I_{1}+I_{2}$ in year 2 , and $\sum_{s=1}{ }^{\top} I_{s}$ in year $T$, where $I_{s}$ is the number of producers in year $\mathrm{s}$.

The convexity constraint $\sum_{i} \lambda_{i}=1$ allows the approximating technology $\mathrm{T}^{t}$ to satisfy variable returns to scale and to envelop the data tightly. Deleting the constraint would impose constant returns to scale on $\mathrm{T}^{\mathrm{t}}$ and would not allow the technology to envelop the data as closely. Moreover, cooperatives are expected to operate in the increasing returns to scale segment of the technology for a variety of reasons, including attenuated access to external finance. Since the per-worker technology relates $y=Y / L$ to $x=X / L$, imposing 
Grifell-Tatjé, E. and C.A. Knox Lovell (2004), "Decomposing the Dividend," Journal of Comparative Economics vol. 32, issue 3, pages 500 - 518.

DOI: $10.1016 /$ j.jce.2004.05.002

constant returns to scale would require increasing returns to scale in the technology relating $Y$ to $(X, L)$. Since we prefer to test for returns to scale rather than impose a restriction, we retain the convexity constraint.

The cost-efficient normalized input bundle, denoted $\mathrm{X}_{\mathrm{CE}}{ }^{\mathrm{t}}$ in Figure 2,

minimizes the other input cost of producing $y^{t}$, given other input prices $w^{t}$ and technology $\mathrm{T}^{\mathrm{t}}$ as defined in (5). To identify this bundle, we solve the following linear program for each cooperative, $\mathrm{i}=1, \ldots,{ }^{\circ}, \ldots, \mathrm{I}_{\mathrm{t}}$, in each year, $\mathrm{t}=1, \ldots, \mathrm{T}$.

$$
\begin{aligned}
\mathrm{XCE}^{\mathrm{O}^{\mathrm{t}}}=\min _{\mathrm{x}} \mathrm{w}^{\mathrm{otT} \mathrm{x}} & \\
\text { s.t. } \quad & \mathrm{x} \geqq \sum_{\mathrm{i}} \lambda_{\mathrm{i}} \mathrm{x}_{\mathrm{i}}^{\mathrm{s}} \\
& \mathrm{y}^{\mathrm{ot}} \leqq \sum_{\mathrm{i}} \lambda_{\mathrm{i}} \mathrm{y}_{\mathrm{i}}^{\mathrm{s}} \\
& \lambda_{\mathrm{i}} \geqq 0, \sum_{\mathrm{i}} \lambda_{\mathrm{i}}=1 .
\end{aligned}
$$

For any cooperative designated $\mathrm{o}$ in year $\mathrm{t}$, the cost-efficient normalized input vector $\mathrm{XCE}_{\mathrm{C}^{\mathrm{t}}}$ is the vector $\mathrm{x}$ that minimizes w $^{\text {otT }} \mathrm{X}$, subject to the constraint that

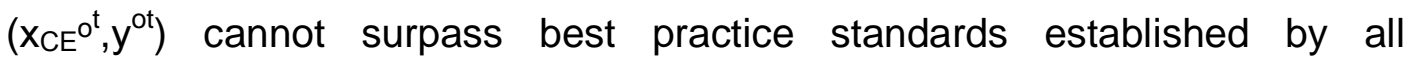
cooperatives in all years prior to and including year t. This program is solved $\sum_{S=1}{ }^{\mathrm{T}} \mathrm{I}_{\mathrm{s}}$ times, once for each cooperative in each year. 
Grifell-Tatjé, E. and C.A. Knox Lovell (2004), "Decomposing the Dividend," Journal of Comparative Economics vol. 32, issue 3, pages 500 - 518.

DOI: $10.1016 /$ j.jce.2004.05.002

The new technology output per worker, denoted $y^{\text {At }}$ in Figure 2, represents the maximum output per worker that could be obtained from using cost-efficient $\mathrm{XCE}^{t}$ with the new technology, $\mathrm{T}^{\mathrm{t}+1}$. To identify this point, we solve the following linear program for each cooperative, $\mathrm{i}=1, \ldots,{ }^{\circ}, \ldots, \mathrm{I}_{\mathrm{t}}$, in each year, $\mathrm{t}=1, \ldots, \mathrm{T}-1$.

$$
\mathrm{y}^{\mathrm{oAt}} / \mathrm{y}^{\mathrm{ot}}=\max _{\phi} \phi
$$

s.t. $\quad \mathrm{X}_{\mathrm{CE}}{ }^{\mathrm{ot}} \geqq \sum_{\mathrm{i}} \lambda_{\mathrm{i}} \mathrm{X}_{\mathrm{CE}}{ }^{\mathrm{s}+1}$

$$
\begin{aligned}
\phi y^{\mathrm{ot}} & \leqq \sum_{i} \lambda_{\mathrm{i}} \mathrm{y}_{\mathrm{i}}^{\mathrm{s}+1} \\
\lambda_{\mathrm{i}} & \geqq 0, \sum_{\mathrm{i}} \lambda_{\mathrm{i}}=1 .
\end{aligned}
$$

For cooperative $\mathrm{o}$ in year $\mathrm{t}$, the program seeks the maximum expansion of $\mathrm{y}^{\text {ot }}$ subject to the constraint that $\left(\mathrm{X}_{\mathrm{CE}}{ }^{\mathrm{ot}}, \phi \mathrm{y}^{\mathrm{ot}}\right)$ cannot surpass best practice standards established by all cooperatives in all years prior to and including year $t+1$. Then the new technology output per worker, denoted $y^{\circ}{ }^{A t}$ is obtained from setting $\mathrm{y}^{\mathrm{o}^{\mathrm{At}}}$ equal to $\phi \mathrm{y}^{\mathrm{ot}}$. This procedure identifies the output per worker that would be feasible with cost-efficient year $t$ normalized inputs $\mathrm{X}_{\mathrm{CE}^{\mathrm{ot}}}$ and 
Grifell-Tatjé, E. and C.A. Knox Lovell (2004), "Decomposing the Dividend," Journal of Comparative Economics vol. 32, issue 3, pages 500 - 518.

DOI: $\underline{10.1016 / \mathrm{j} . j \mathrm{jce} .2004 .05 .002}$

period $t+1$ technology $\mathrm{T}^{\mathrm{t}+1}$, so that it provides a local measure of technical change. This program is solved $\sum_{\mathrm{S}=1}^{\mathrm{T}-1} \mathrm{I}_{\mathrm{S}}$ times, once for each cooperative in each year, but we must exclude the terminal year because data are not available for year $\mathrm{T}+1$.

Solving the above programs yields values of the unobserved quantities, i.e., $\mathrm{X}_{C E}{ }^{\mathrm{t}}, \mathrm{X}_{\mathrm{CE}}{ }^{\mathrm{t}+1}$ and $\mathrm{y}^{\mathrm{At}}$, for all cooperatives in all years. Inserting these quantities into the proposition generates a complete decomposition of variation of the dividend, both over time and across cooperatives. In the next section we use data from our sample of Spanish CFIs to calculate these sources of variation in the dividend of cooperatives.

\section{Data and Decomposition Results}

Summary statistics of the relevant variables for 59 CFIs from 1994 to 2001 are summarized in Table 1. The data are organized according to an intermediation view of financial institution performance in which deposits are combined with other inputs, i.e., labor and non-financial assets, to produce revenue-generating loans and other investments. ${ }^{15}$ Annual mean wages have grown by $3.1 \%$ per year to a 2001 value of nearly $€ 38,000$, while annual mean dividends have grown by $3.9 \%$ per year to a 2001 value of over $€ 70,000$. This growth occurred despite a continuing decline in annual mean rates of return on loans and other investments, by nearly $40 \%$ during the period. $^{16}$ 
Grifell-Tatjé, E. and C.A. Knox Lovell (2004), "Decomposing the Dividend," Journal of Comparative Economics vol. 32, issue 3, pages 500 - 518.

DOI: $10.1016 /$ j.jce.2004.05.002

\section{Insert Table 1 about here}

As expected in an increasingly competitive financial services market, the variation in pricing power is minimal with annual coefficients of variation of output prices and input prices averaging less than 10\% except for nonfinancial assets. In contrast, the coefficients of variation of output quantities and input quantities average $190 \%$. Hence, we expect price effects to be dominated by quantity effects as sources of dividend variation. The relative uniformity of wages, with an average coefficient of variation of $15 \%$, does not imply a relatively efficient allocation of labor because employment decisions depend on the dividend rather than on wages. The coefficient of variation of the dividend has remained stable at an average of $33 \%$ over the period.

Table 2 provides an initial decomposition of the dividend variation, both annually and for the entire period. On average, the dividend increases annually by $€ 2,400$. This growth reflects the impact of a substantial decline in the Bennet price indicator countervailed by a larger increase in the Bennet quantity indicator. In equation (4), the price indicator is quantity-weighted and the quantity indicator is price-weighted. Hence, a negative price effect indicates that price changes lead to an average annual reduction in the dividend of $€ 3,210$. However, this decrease is more than offset by quantity growth that generates an average annual increase in the dividend of $€ 5,610$. 
Grifell-Tatjé, E. and C.A. Knox Lovell (2004), "Decomposing the Dividend," Journal of Comparative Economics vol. 32, issue 3, pages 500 - 518.

DOI: $10.1016 /$ j.jce.2004.05.002

Therefore, dividend performance improves over the period despite a deteriorating price structure. ${ }^{16}$

\section{Insert Table 2 about here}

The final two columns of Table 2 provide an initial decomposition of the quantity effect. Since quantity effects are price-weighted, these results suggest that the value of output per worker increased by far more than did the cost of other inputs per worker. The labor productivity effect generated an average annual increase in the dividend of $€ 11,830$, while the input deepening effect caused an average annual reduction in the dividend of $€ 6,220 .^{18}$ Hence, although input deepening is costly, it is productive and profitable at a positive spread.

Table 3 provides the decomposition of the quantity effect, both annually and for the entire period. The activity effect accounts for more than the entire quantity effect, contributing an average annual increase of $€ 6,480$ to the dividend. This result is consistent with our argument that CFIs are motivated to expand internally by increasing their memberships, which provide the deposits to finance growth. The activity effect is augmented by a small improvement in technology that enhanced labor productivity and led to an average annual increase of $€ 290$ in the dividend. Offsetting these two effects is a general deterioration in cost efficiency that led to an average annual decline of $€ 1,160$. $^{19}$ 
Grifell-Tatjé, E. and C.A. Knox Lovell (2004), "Decomposing the Dividend," Journal of Comparative Economics vol. 32, issue 3, pages 500 - 518.

DOI: $10.1016 /$ j.jce.2004.05.002

\section{Insert Table 3 about here}

To summarize our aggregate time series findings, the observed upward trend in the dividend occurs despite a continuing decline in the spread between the rates of return on loans and investments and interest rates paid to depositors, which generate an adverse price effect. In addition, input deepening is costly and generates an adverse impact on the quantity effect. However, input deepening has three impacts on the increase in labor productivity, two of which are favorable. Increases in deposits per worker fund increases in loans and investments per worker, which enhances labor productivity and raises the dividend because the spread is positive although declining. Increases in non-financial capital per worker, e.g., investments in information technology, generate improvements in technology, which also enhances labor productivity and raises the dividend. However, input deepening does not occur in a cost-efficient manner, given input price trends; the decline in cost efficiency causes a small reduction in labor productivity and reduces the dividend. Ironically, the decline in cost efficiency can be traced to over-investment in non-financial capital, the price of which declined modestly, rather than to excessive deposit taking, the price of which declined dramatically in the middle half of the period. ${ }^{20}$

\section{Comparisons Between CLP and Other Spanish CFIs}


Grifell-Tatjé, E. and C.A. Knox Lovell (2004), "Decomposing the Dividend," Journal of Comparative Economics vol. 32, issue 3, pages 500 - 518.

DOI: $\underline{10.1016 / \mathrm{j} . j \mathrm{jce} .2004 .05 .002}$

In this section, we turn our attention to an investigation into disaggregate cross section variation in the dividend. We conduct a sequence of annual benchmarking exercises in which the financial performance of individual CFls is compared to that of CLP. Although CLP did not earn the largest dividend in any year, we choose it as a benchmark because it is the largest and most widely known CFI. To decompose cross-sectional dividend variation, we follow the same procedure used for the aggregate time series analysis with two exceptions. First, variation now refers to the difference between CLP and each other CFI. Hence, $\left(D^{t+1}-D^{t}\right)$ becomes $\left(D^{C L P}-D^{C F I}\right)$, and similar changes are made for all other variables. Second, technical change is not feasible in a single year; hence, the technical change effect disappears and dividend variation decomposes into an activity effect and a cost efficiency effect only. ${ }^{21}$

The results of these exercises are reported in Tables 4 and 5. Table 4 contains benchmarking results averaged over CFIs having smaller dividends than CLP to investigate what these less-successful CFIs can learn from CLP. Table 5 contains benchmarking results averaged over CFIs having larger dividends than CLP to investigate what CLP can learn from these moresuccessful CFIs. The number of less-successful CFIs varies from 45 to 56 , while the number of more-successful CFls ranges from two to 13. Since both sets of benchmarking results are consistent from year to year, we discuss the 2001 results, and note one important discrepancy. 
Grifell-Tatjé, E. and C.A. Knox Lovell (2004), "Decomposing the Dividend," Journal of Comparative Economics vol. 32, issue 3, pages 500 - 518.

DOI: $10.1016 /$ j.jce.2004.05.002

\section{Insert Tables $\mathbf{4}$ and 5 about here}

In 2001, CLP generated a dividend that was $€ 32,620$ larger than the average dividend earned by the 47 less-successful CFIs. Since CLP had a slightly less favorable price structure, the entire dividend difference of $€ 36,540$ is attributable to CLP's larger quantity effect. Although CLP incurred deposit and operating expenses averaging nearly $€ 60,000$ more than those of the less-successful CFIs, input deepening raised the value of output per worker at CLP by nearly $€ 100,000$ over that of the less-successful CFIs. This result is partly due to the almost one million depositors of the 130 Mondragón cooperatives that are members of CLP. The better performance also reflects the superior ability of CLP to convert deposits to loans, despite a smaller-tanaverage spread of $3.1 \%$. Our decomposition of the quantity effect offers additional insight into CLP's dividend advantage. The quantity effect is attributable to a $€ 55,260$ activity effect, which is offser partially by a $€ 18,720$ cost efficiency reduction that reflects CLP's excessive reliance on nonfinancial capital. The decomposition results are consistent over time with the sole exception that CLP typically enjoyed a relatively favorable price structure. The lesson for less-successful CFIs is to attract more deposits and exploit their more favorable spread. ${ }^{22}$

The benchmarking results relative to the seven more-successful CFIs in 2001 are smaller in magnitude. Compared to these cooperatives, CLP has a dividend disadvantage of $€ 16,580$ even though its price structure is 
Grifell-Tatjé, E. and C.A. Knox Lovell (2004), "Decomposing the Dividend," Journal of Comparative Economics vol. 32, issue 3, pages 500 - 518.

DOI: $10.1016 /$ j.jce.2004.05.002

relatively favorable. The negative quantity effect may be attributed to a lower value of output per worker despite more extensive input deepening at CLP. Alternatively, it may be attributed to lower cost efficiency at CLP, augmented by a negative activity effect. The lesson for CLP from more-successful CFIs is to improve cost efficiency first, and then implement procedures to facilitate the conversion of deposits to loans and investments at a more favorable spread.

To summarize the results of the two benchmarking exercises, CLP has a more favorable price structure in all years, except 2001, and lower cost efficiency in all years than either more-successful or less successful cooperatives. Since these effects are almost offsetting and the technology effect is irrelevant in cross-sectional analysis, the activity effect becomes the key determinant of dividend performance. The activity effect is a quantity effect that is net of variation in technology and the differences in cost efficiency. By this measure, CLP is more productive than the less-successful CFIs and less productive than the more-successful CFIs. Because the value of loans and investments is highly correlated with the value of deposits, this productivity variation is the main source of dividend variation. Over the entire sample, the ratio of the value of loans and investments to the value of deposits averages 1.05, with a standard deviation of 0.04 . In 2001, six of the seven more-successful CFls had ratios above that of CLP's at 1.07 and 44 of the 47 less-successful CFIs had ratios below that of CLP. Although input deepening is costly, a positive spread generates a proportionately larger value of output per worker and consequently a dividend advantage. This 
Grifell-Tatjé, E. and C.A. Knox Lovell (2004), "Decomposing the Dividend," Journal of Comparative Economics vol. 32, issue 3, pages 500 - 518.

DOI: $\underline{10.1016 / \mathrm{j} . j \mathrm{jce} .2004 .05 .002}$

result indicates that the ability to attract deposits and the ability to convert deposits to revenue-earning loans and investments are crucial to better dividend performance.

\section{Summary and Conclusions}

Dividend-seeking cooperatives of the Ward-Domar type adjust employment to equate the value of labor's marginal product with the value of the endogenously determined dividend. Therefore, variation in the dividend implies variation in the value of labor's marginal product leading to an inefficient allocation of labor among cooperatives. Limited labor mobility makes it likely that this resource misallocation will persist. We investigate the sources of dividend variation analytically and apply our technique to a panel of 59 Spanish cooperative financial institutions over the period from 1994 to 2001.

Our aggregate time series results indicate that dividend growth has been due primarily to input deepening, which has enhanced the value of output per worker more than proportionately to its cost. However, a substantial decline in returns on loans and investments, which was only partly offset by a smaller decline in interest paid on deposits, contributed adversely to dividend growth. Our cross-sectional benchmarking results in which we compare less-successful and more-successful CFIs to CLP reinforces the finding that input deepening is critical. Increases in deposits per worker generate proportionately larger increases in loans and investments per 
Grifell-Tatjé, E. and C.A. Knox Lovell (2004), "Decomposing the Dividend," Journal of Comparative Economics vol. 32, issue 3, pages 500 - 518.

DOI: $10.1016 /$ j.jce.2004.05.002

worker, which earn a positive spread. Variation in cost efficiency is large but it is unrelated to dividend performance as both groups are more cost-efficient than CLP. Variation in the price structure is also large and positively related to dividend performance in all years except for 2001.

Our results have implications for the misallocation of labor in a cooperative economy. Our data indicate that dividend variation has been large and persistent, with coefficient of variation remaining stable at 0.33 . In 2001, one employee moving from a CFI with a dividend that is one standard deviation below the sample mean to a CFI with a dividend that is one standard deviation above the mean would generate a decline in the value of labor's marginal product of $€ 49,460$ at the former and an increase of $€ 92,160$ in the latter for a net gain of $€ 42,700$. This example indicates the cost of institutional and cultural constraints on the mobility of labor in the sector. In the financial sector, deposits are the source of loans and investments, so that variation in the ability to attract deposits and to convert them to profitable loans and investments is a critical source of dividend variation, and hence to labor misallocation. To the extent that variation in the ability to attract and convert deposits persists or increases among Spanish cooperative financial institutions, dividend variation and labor misallocation are likely to continue. The misallocation is particularly acute in Spain because labor mobility is culturally constrained. 
Grifell-Tatjé, E. and C.A. Knox Lovell (2004), "Decomposing the Dividend," Journal of Comparative Economics vol. 32, issue 3, pages 500 - 518.

DOI: $10.1016 /$ j.jce.2004.05.002

\section{Footnotes}

${ }^{1}$ We are grateful to Ministerio de Ciencia y Technologia, SEC2001-2793C03-01, Generalitat de Catalunya, 2001SGR 00159, for their financial support, and to Pablo Font de Mora Sainz and Carmen Conde Rodriguez of UNACC for their assistance. A previous version of this paper was presented at the VIII European Workshop on Efficiency and Productivity Analysis, Oviedo, Spain. We are grateful to the audience for their comments and to the Editor and two referees for their very constructive criticism of that version.

${ }^{2}$ A comparative exercise would be interesting because CFls operate in an institutional environment similar to that of other commercial and savings banks, although savings banks are prohibited from issuing equity capital, and because detailed data are available for all three institutional types. However we focus on performance variation among CFIs because this variation has implications for a recurring theme in the theoretical literature that has not been studied empirically, namely, the inefficient allocation of labor among cooperatives.

3 Palomo (2000), Rodero Franganillo (1974) and Terrón Muñoz (1984) provide historical information. UNACC policies can be found at http://www.unacc.com. The procedures of most individual CFIs are reported 
Grifell-Tatjé, E. and C.A. Knox Lovell (2004), "Decomposing the Dividend," Journal of Comparative Economics vol. 32, issue 3, pages 500 - 518.

DOI: $10.1016 /$ j.jce.2004.05.002

at http://www.unacc.com/defcajas.htm and the procedures of CLP are listed at http://www.cajalaboral.com. Thomas and Logan (1983) provide a good description of Mondragón; the policies of Mondragón Corporación Cooperativa are available at http://www.mondragon.mcc.es.

${ }^{4}$ INE (2001) reports that only $0.83 \%$ of Spanish workers moved to another province in 2001 , and only $2.4 \%$ of Spanish workers moved to another municipality, within or outside their home province.

5 This evidence is based on discussions with staff at UNACC and detailed information from auditors' reports for 35 CFIs in 2001 and five CFIs in 2002. All of these CFIs are included in our sample.

${ }^{6}$ A partial list of additional benefits includes a quarterly salary bonus equal to one month's pay, full National Health Service benefits, a pension plan, a thirty-day paid vacation, paid leaves of absence for a variety of reasons, the availability of subsidized loans, educational support for employees and their children, and widow and orphan funds.

${ }^{7}$ Excluding CLP and CP, which allocate $51 \%$ and $100 \%$, respectively, of their Asamblea General funds to member cooperatives, and CR de Canarias, which allocates $90 \%$ of its Asamblea General funds to Investment for Canarias, $88 \%$ of the disbursements are put in the reserve fund. 
Grifell-Tatjé, E. and C.A. Knox Lovell (2004), "Decomposing the Dividend," Journal of Comparative Economics vol. 32, issue 3, pages 500 - 518.

DOI: $10.1016 /$ j.jce.2004.05.002

8 We find evidence that CFls limit employment relative to comparison institutions. Palomo (2000) reports that, in 1999, CFIs had 3.7 employees per branch office, while savings banks had 5.3 and commercial banks had 7.7. CFIs were also more profitable, having a ROA of $1.20 \%$ compared with ROAs of $0.94 \%$ at savings banks and $0.66 \%$ at commercial banks.

${ }^{9}$ Diewert (1998) provides a list of axioms satisfied by Bennet indicators and proves that Bennet indicators are invariant to changes in the units of measurement, so that $\mathrm{I}\left(\mathrm{p}^{\mathrm{t}}, \mathrm{p}^{\mathrm{t}+1}, \mathrm{q}^{\mathrm{t}}, \mathrm{q}^{\mathrm{t}+1}\right)=\mathrm{I}\left(\lambda \mathrm{p}^{\mathrm{t}}, \lambda \mathrm{p}^{\mathrm{t}+1}, \lambda^{-1} \mathrm{q}^{\mathrm{t}}, \lambda^{-1} \mathrm{q}^{\mathrm{t}+1}\right)$ for any $\lambda>0$. Balk et al. (2004) claim that Bennet indicators are dimensionally invariant with the dimension being money. All components of the Bennet indicators in equation (4) are expressed in terms of euros. If all quantities are scaled by a positive $\lambda$, the corresponding prices are scaled by $\lambda^{-1}$ and nothing changes.

${ }^{10}$ The decomposition in equation (4) is analogous to a decomposition of profit found in the business literature, in which the price effect reflects the ability to pass through input price changes, as Miller (1984) explains.

11 Our decomposition of dividend variation is structurally similar to the decomposition of the variation in the gross return to capital defined in Lawrence et al. (2003), and in our notation $G=\pi+w_{K} K$. Normalizing $G$ by $K$ 
Grifell-Tatjé, E. and C.A. Knox Lovell (2004), "Decomposing the Dividend," Journal of Comparative Economics vol. 32, issue 3, pages 500 - 518.

DOI: $\underline{10.1016 / \mathrm{j} . j \mathrm{jce} .2004 .05 .002}$

generates a gross rate of return on capital that is structurally identical to D, with $w_{K}$ and $K$ replacing $w_{L}$ and $L$. However we use Bennet indicators and they use Törnqvist indexes.

12 In Figure 2 the activity effect may also be measured along $\mathrm{T}^{\mathrm{t}}$ with the technology effect measured at $\mathrm{x}_{\mathrm{CE}}^{\mathrm{t}+1}$.

${ }^{13}$ DEA is used to examine technical and scale efficiencies of Spanish CFIs by Millán (1997). An alternative frontier technique, stochastic frontier analysis, is used by Marco Gual and Moya Clemente (1999) to estimate scale economies and cost efficiency among Spanish CFIs. However, neither study is concerned with financial performance as reflected by the dividend. Both frontier techniques are used frequently to evaluate the performance of cooperative organizations and to compare their performance with that of capitalist twins.

14 Tulkens and Vanden Eeckaut (1995) refer to this approach as sequential DEA; this technique does not allow technical regress because all previous technologies are incorporated in $\mathrm{T}^{\mathrm{t}}$.

15 These data are obtained from annual reports of Memorias de la Unión Nacional de la Asociación de Cooperativas de Crédito. The population of 
Grifell-Tatjé, E. and C.A. Knox Lovell (2004), "Decomposing the Dividend," Journal of Comparative Economics vol. 32, issue 3, pages 500 - 518.

DOI: $10.1016 /$ j.jce.2004.05.002

Spanish CFIs remained at 95 from 1994 through 1998 and declined to 88 by 2001. We deleted all CFIs with fewer than 15 employees and a few others having missing or inconsistent data. The decline in sample size from 59 to 55 in 2001 is due to two mergers.

${ }^{16}$ To put these nominal figures in perspective, inflation averaged $3 \%$ per year over the period. Regardless of whether labor income is measured by wages or the dividend, real growth has occurred. Nonetheless, incomes of CFI employees are not out of line with those of employees at capitalist twins. Over the sample period, employee wages at savings banks averaged $26 \%$ higher, with the same coefficient of variation, and wages at commercial banks averaged $22 \%$ higher, with a larger coefficient of variation. However, employees of commercial banks do not receive benefits comparable to those given to cooperative employees from the available surplus. Relatively high wages in Spanish financial institutions are a lingering consequence of a tightly regulated system, which had been closed to most foreign competition. Caminal et al. (1993) provide an interesting history of the Spanish financial system.

17 The deteriorating price structure is reflected in a narrowing spread between returns on loans and investments and interest paid on deposits from $4.8 \%$ to $3.8 \%$. On average, declining returns on loans and investments reduced the Bennet output price indicator by $€ 11,540$, while smaller but still substantial 
Grifell-Tatjé, E. and C.A. Knox Lovell (2004), "Decomposing the Dividend," Journal of Comparative Economics vol. 32, issue 3, pages 500 - 518.

DOI: $10.1016 /$ j.jce.2004.05.002

declines in deposit rates made up $€ 8,090$ of the $€ 8,330$ reduction in the Bennet input price indicator.

18 The input deepening effect of $-€ 6,220$ decomposes into a cost of deposits per worker effect of $-€ 5,240$ and a cost of capital per worker effect of $-€ 980$, averaged over all institutions and all years. Thus, the major source of input deepening has been an increase in deposits, which are used to fund loans and investments.

${ }^{19}$ We also calculated the two DEA exercises on the underlying technology, with and without the convexity constraint, to investigate the presence of scale economies. Furubotn and Pejovich (1970) and Vanek (1977) claim that attenuated property rights constrain cooperatives to operate in the increasing returns to scale region. We find that the variable returns to scale technology envelops the data more closely than does the constant returns to scale technology. Over all CFIs and all years, the ratio of minimum non-labor cost under constant returns to scale to minimum non-labor cost under variable returns to scale averages 0.920 with a standard deviation of 0.088 . The two largest and the three smallest CFls have the smallest mean ratios in the sample at approximately 0.7 . This pattern is consistent with a classical Ushaped average cost frontier, so it provides only modest support for the attenuated property rights hypothesis. 
Grifell-Tatjé, E. and C.A. Knox Lovell (2004), "Decomposing the Dividend," Journal of Comparative Economics vol. 32, issue 3, pages 500 - 518.

DOI: $10.1016 /$ j.jce.2004.05.002

20 This finding of over-investment in non-financial capital at CFIs in the 1990s is consistent with general findings for financial institutions. Although information technology may be the engine of productivity growth, it typically works with a lag as institutions move down their learning curves.

${ }^{21}$ In any given year, individual CFIs adopt different production practices but cross-section analysis is capable of constructing only a single best practice technology.

${ }^{22}$ CLP's favorable large price indicator in all years except 2001 in Table 4 and in all years in Table 5 does not indicate pricing power. As Table 1 shows, little price variation is found across CFIs in any given year although considerable intertemporal price variation exists. CLP's large price effect is due to large quantity weights rather than to large price differences. For example, ( $p^{C L P}-$ $\left.p^{C F I}\right)=0.32 \%,\left(w_{1}{ }^{C L P}-w_{1}{ }^{C F I}\right)=0.47 \%$, and $\left(w_{2}{ }^{C L P}-w_{2}{ }^{C F I}\right)=-0.26 \%$ for all benchmarking CFIs in 2000. 
Grifell-Tatjé, E. and C.A. Knox Lovell (2004), "Decomposing the Dividend," Journal of Comparative Economics vol. 32, issue 3, pages 500 - 518.

DOI: $10.1016 /$ j.jce.2004.05.002

\section{References}

Balk, Bert, Färe, Rolf and Grosskopf, Shawna, 2004. The Theory of Economic Price and Quantity Indicators. Economic Theory 23, 149-164.

Ben - Ner, Avner, 1984. On the Stability of the Cooperative Type of Organization. Journal of Comparative Economics 8, 247-260.

Bennet, T. L., 1920. The Theory of Measurement of Changes in Cost of Living. Journal of the Royal Statistical Society 83, 455-462.

Bonin, John P., Jones, Derek C., and Putterman, Louis, 1993. Theoretical and Empirical Studies of Producer Cooperatives: Will Ever the Twain Meet? Journal of Economic Literature 31, 1289-1320.

Bradley, Keith, and Gelb, Alan, 1982. The Mondragon Cooperatives: Guidelines for a Cooperative Economy? In: Jones, Derek C., and Svejnar, Jan (Eds.), Participatory and Self-Managed Firms. D. C. Heath \& Co., Lexington, MA, pp. 153-172. 
Grifell-Tatjé, E. and C.A. Knox Lovell (2004), "Decomposing the Dividend," Journal of Comparative Economics vol. 32, issue 3, pages 500 - 518.

DOI: $\underline{10.1016 / \mathrm{j} . j \mathrm{jce} .2004 .05 .002}$

Caminal, Ramon, Gual, Jordi, and Vives, Xavier, 1993. Competition in Spanish Banking. In: Dermine, Jean, (Ed.), European Banking in the 1990s, Second Edition. Blackwell Publishers, Oxford, pp. 271-321.

Charnes, Abraham, Cooper, William W., and Rhodes, Edwardo, 1978. Measuring the Efficiency of Decision Making Units. European Journal of Operational Research 2, 429-444.

Diewert, W. Erwin, 1998. Index Number Theory Using Differences Rather than Ratios. Discussion Paper No. 98-10, Department of Economics, University of British Columbia, Vancouver V6T 1Z1, Canada.

Domar, Evsey D., 1966. The Soviet Collective Farm as a Producer Cooperative. American Economic Review 56, 734-757.

Estrin, Saul, Jones, Derek C., and Svejnar, Jan, 1987. The Productivity Effects of Worker Participation: Producer Cooperatives in Western Economies. Journal of Comparative Economics 11, 40-61.

Furubotn, Eirik G., and Pejovich, Svetozar, 1970. Property Rights and the Behavior of the Firm in a Socialist State: The Example of Yugoslavia. Zeitschrift für Nationalökonomie 30, 431-454. 
Grifell-Tatjé, E. and C.A. Knox Lovell (2004), "Decomposing the Dividend," Journal of Comparative Economics vol. 32, issue 3, pages 500 - 518.

DOI: $\underline{10.1016 / \mathrm{j} . j \mathrm{jce} .2004 .05 .002}$

Instituto Nacional de Estadistica (INE), 2001. Estadistica de Variaciones Residenciales. Madrid.

Ireland, Norman J., and Law, Peter J., 1981. Efficiency, Incentives, and Individual Labor Supply in the Labor-Managed Firm. Journal of Comparative Economics 5, 1-23.

Kahana, Nava, 1989. The Duality Approach in the Case of Labour-Managed Firms. Oxford Economic Papers 41, 567-572.

Lawrence, Denis, Diewert, W. Erwin and Fox, Kevin, 2003. The Contribution of Productivity, Price Changes and Firm Size to Profitability. Revision of Discussion Paper No. 01-09, Department of Economics, University of British Columbia, Vancouver, Canada V6T 1 Z1.

Marco Gual, M. Amparo, and Moya Clemente, Ismael, 1999. Inefficiency in the Spanish Cooperative Banking Sector. Annals of Public and Cooperative Economics 70, 621-637.

Millán, Joaquin. A., 1997. Eficiencia de Escala y Eficiencia Tecnica en las Cajas Rurales: un Analisis no Parametrico. Investigaciones de Agricultura Economica 12, 103-116. 
Grifell-Tatjé, E. and C.A. Knox Lovell (2004), "Decomposing the Dividend," Journal of Comparative Economics vol. 32, issue 3, pages 500 - 518.

DOI: $\underline{10.1016 / \mathrm{j} . j \mathrm{jce} .2004 .05 .002}$

Miller, David M., 1984. Profitability = Productivity + Price Recovery. Harvard Business Review 62, 145-153.

Miyazaki, Hajime, 1984. On the Success and Dissolution of the Labor managed Firm in the Capitalist Economy. Journal of Political Economy 92, $909-931$.

Neary, Hugh M., 1988. The Comparative Statics of the Ward - Domar Labor - Managed Firm: A Profit Function Approach. Journal of Comparative Economics 12, 159-181.

Palomo, Ricardo J., 2000. Pasado, Presente y Futuro de la Banca Cooperativa en España. CIRIEC-España, Madrid.

Pencavel, John, 2001. Worker Participation: Lessons from the Worker Co-ops of the Pacific Northwest. Russell Sage Foundation, New York.

Rodero Franganillo, Adolfo, 1974. Las Cajas Rurales Españolas. Ediciones ICE, Madrid.

Terrón Muñoz, Federico, 1984. Las Cajas Rurales Españolas: Nacimiento, Auge y Perspectivas del Cooperativismo Agrario Crediticio en España. Instituto de Desarrollo Regional de la Universidad de Granada, Granada. 
Grifell-Tatjé, E. and C.A. Knox Lovell (2004), "Decomposing the Dividend," Journal of Comparative Economics vol. 32, issue 3, pages 500 - 518.

DOI: $10.1016 /$ j.jce.2004.05.002

Thomas, Henk, and Logan, Chris, 1983. Mondragon: An Economic Analysis. George Allen \& Unwin, London.

Tulkens, Henry, and Vanden Eeckaut, Philippe, 1995. Non-Parametric Efficiency, Progress and Regress Measures For Panel Data: Methodological Aspects. European Journal of Operational Research 80, 474-499.

Vanek, Jaroslav, 1977. The Basic Theory of Financing of Participatory Firms. In: Vanek, Jaroslav (Ed.), The Labor-Managed Economy: Essays by Jaroslav Vanek. Cornell University Press, Ithaca, NY, pp. 186-198.

Ward, Benjamin, 1958. The Firm in Illyria: Market Syndicalism. American Economic Review 48, 566-589. 
Grifell-Tatjé, E. and C.A. Knox Lovell (2004), "Decomposing the Dividend," Journal of Comparative Economics vol. 32, issue 3, pages 500 - 518.

DOI: $10.1016 /$ j.jce.2004.05.002

Figure 1 Decomposing the Dividend

Figure 2 Decomposing the Quantity Effect 
Grifell-Tatjé, E. and C.A. Knox Lovell (2004), "Decomposing the Dividend," Journal of Comparative Economics vol. 32, issue 3, pages 500 - 518.

DOI: $\underline{10.1016 / \text { j.jce.2004.05.002 }}$

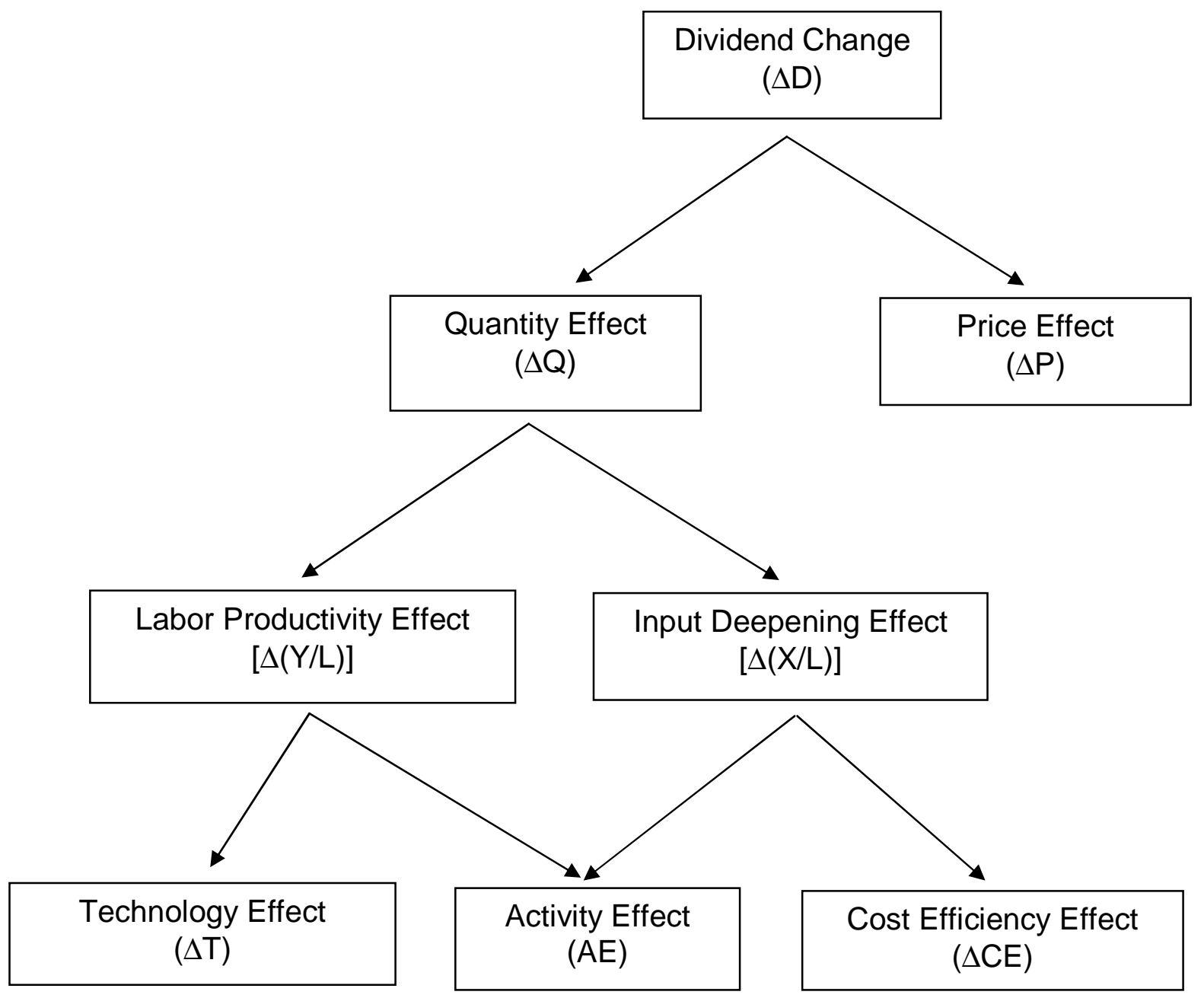


Grifell-Tatjé, E. and C.A. Knox Lovell (2004), "Decomposing the Dividend," Journal of Comparative Economics vol. 32, issue 3, pages 500 - 518.

DOI: $10.1016 /$ j.jce.2004.05.002

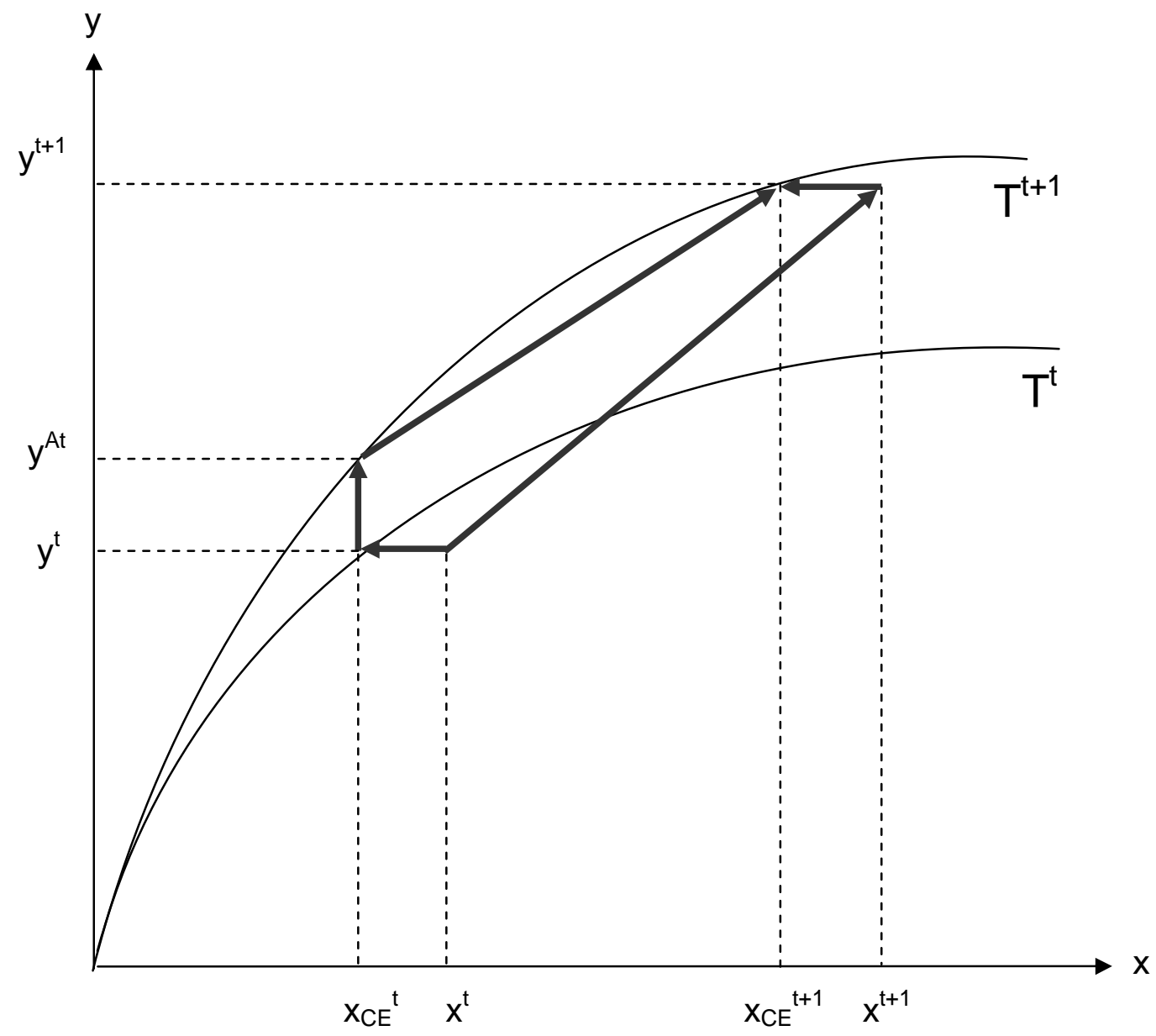


